\title{
Effects of algal food concentration and body size on the ingestion rates of Ruditapes decussatus (Bivalvia) veliger larvae
}

\author{
A. Pérez-Camacho, R. Beiras, M. Albentosa \\ Instituto Español de Oceanografía, PO Box 130, E-15080 A Coruña, Galicia, Spain
}

\begin{abstract}
Feeding rates of Ruditapes decussatus clam larvae from the D-shaped stage to metamorphosis were recorded at algal food concentrations ranging between 10 and 300 Isochrysis galbana cells $\mu \mathrm{I}^{-1}$ The ingestion rate was an allometric function of the organic weight of larvae (IR $=a \mathrm{AFDW} \mathrm{W}^{b}$ ) with exponents between 0.40 and 0.88 , increasing with concentration. The ingestion rate was also directly related to food concentration up to an optimum at $200 \mathrm{cells}^{\mathrm{ul}} \mathrm{l}^{-1}$, beyond which it remained almost constant. The response of the ingestion rate to particle concentration could be described by assuming increasing interference among particles that reduces the efficiency of capture by $R$. decussatus of algal cells. Considering the unique mechanism of feeding in veligers, maximum ingestion capacity (cells $\mathrm{h}^{-1}$ ) - rather than maximum clearance rate $\left(\mu \mathrm{h} \mathrm{h} \mathrm{h}^{-1}\right)$, widely studied in physiological energetics of adult molluscs - is proposed as a more adequate indicator of maximum energy gain in bivalve larvae.
\end{abstract}

KEY WORDS: Veliger larvae · Food concentration - Ingestion rates

\section{INTRODUCTION}

The application of physiological energetics methods to bivalves enables us to predict or explain the growth of specimens exposed to known environmental conditions on the basis of their energy balance (e.g. Dame 1972, Thompson \& Bayne 1974, Newell et al. 1977 , Griffiths \& King 1979, Bayne \& Worrall 1980, Navarro \& Winter 1982, Widdows \& Johnson 1988, Beiras et al. 1993, 1994a). One of the environmental factors exerting a leading influence on the growth of bivalves is ingested food, which is directly related to its availability (e.g. for larvae see Walne 1965 and Pérez-Camacho et al. 1977; for adults see recent review by Griffiths \& Griffiths 1987). Physiological energetics studies on bivalve larvae have focused on oyster (Wilson 1979, Crisp et al. 1985), mussel (Sprung 1984a, b), and pectinidae (MacDonald 1988), whereas information on the ecologically and commercially relevant Veneridae family is still lacking. In a previous study, we evaluated the influence of the other major environmental factor, temperature, on the energetics of Ruditapes decussatus larvae (Beiras et al. 1994b). Here we explore the interrelations among food concentration, larval size and larval feeding rates throughout the complete larval development of this species.

\section{MATERIAL AND METHODS}

Eggs and sperm were obtained by thermal induction of spawning on adult ( 4 to $5 \mathrm{~cm}$ ) Ruditapes decussatus clams conditioned in our laboratory at $20^{\circ} \mathrm{C}$ and with abundant algal food (a mixed diet of Isochrysis galbana, Tetraselmis suecica and Phaeodactylum tricornutum). Fertilization was conducted using 10 sperm per egg. Fertilized eggs were incubated in $50 \mathrm{l}$ flat bottom tanks at $20^{\circ} \mathrm{C}$ and 1000 eggs $\mathrm{cm}^{-2}$. Seawater used was prefiltered $(1 \mu \mathrm{m})$, UV sterilized, and previously dissolved chloramphenicol (10 $\left.\mathrm{mg} \mathrm{l}^{-1}\right)$ was added to further retard bacterial growth (Pérez-Camacho \& Román 1973). After $48 \mathrm{~h}$, swimming D-stage larvae were collected from the surface of the tanks and transferred to strongly aerated, cylindro-conical fiberglass tanks of $400 \mathrm{l}$, where larvae were reared at $10 \mathrm{ml}^{-1}$ in treated seawater at $19 \pm 1^{\circ} \mathrm{C}$. Larvae were routinely 
fed on $I$. galbana $\left(100\right.$ cells $\left.\mu l^{-1}\right)$ every $2 \mathrm{~d}$, after the water was changed.

Triplicate samples of larvae were transferred at 4 developmental stages (Days 4, 11, 17 and 21) to 11 beakers and fed on 10, 50,100, 200 and 300 Isochrysis galbana cells $\mathrm{\mu l}^{-1}$. A control beaker without larvae was also set up. The decrease in cell concentration after a few hours was then recorded by using a TAII Coulter Counter fitted with a $100 \mu \mathrm{m}$ aperture sampling tube. Experiments were terminated before the cell concentration decrease exceeded $25 \%$. With these data, ingestion rate (IR, cells $\mathrm{h}^{-1}$ ) and clearance rate (CR, $\mu \mathrm{h}^{-1}$ ) were calculated following the equations (Beiras 1992):

$$
\begin{aligned}
\mathrm{IR} & =V / \mathrm{n} t\left[\left(c_{0}-c_{1}\right)-\left(c_{0}^{\prime}-c_{1}^{\prime}\right)\right] \\
\mathrm{CR} & =V / \mathrm{n} t\left[\ln \left(c_{0} / c_{1}\right)-\ln \left(c_{0}^{\prime}{ }_{0} / c^{\prime}{ }_{1}\right)\right]
\end{aligned}
$$

where $V$ is volume, $\mathrm{n}$ is the number of larvae, $t$ is time, $c_{0}$ and $c_{1}$ are the initial and final cell concentrations respectively and $c_{0}^{\prime}$ and $c_{1}^{\prime}$ are the initial and final cell concentrations in the controls.

Larval length (anterior-posterior axis) was recorded on a sample of larvae by using a microscope with a graduated eyepiece. The weight of individual larvae was obtained by counting samples, under the binocular microscope, in a $1 \mathrm{ml}$ counting cell, transferring them to Whatman GFC filters, drying them at $100^{\circ} \mathrm{C}$ to constant weight and ashing them in a furnace at $450^{\circ} \mathrm{C}$ until a constant weight was obtained (see further details in Beiras et al. 1990).

Multifactor analysis of variance (ANOVA) (Sokal \& Rohlf 1969), type I, was used to test the effect of larval size and food concentration (both factors were fixed) on the feeding rates. The ingestion and clearance rate data were also logarithmically (base e) transformed and fitted to multiple regression models using a stepping procedure that excluded variables not reaching the level of statistical significance $(\mathrm{p}=$ 0.05). Statistical analyses were performed using Statgraphics computer software.

\section{RESULTS}

\section{Larval size}

Allometric growth of clam larvae could be described by the equations ( $S E$ of the fitting parameters in parentheses):

$\mathrm{DW}=1.66 \times 10^{-7}(0.039) L^{3.01(0.078)}, \mathrm{r}=0.999, \mathrm{p}<0.001$

AFDW $=0.89 \times 10^{-7}(0.023) L^{2.95(0.079)}, r=0.999, p<0.001$

where $L$ is length $(\mu \mathrm{m}), D W$ is dry weight $(\mu \mathrm{g})$ and AFDW is ash-free dry weight ( $\mu \mathrm{g})$.

Both ingestion and clearance rates were power functions of larval size, expressed as ash-free dry weight,
Table 1. Ruditapes decussatus. Parameters of the allometric equations express ingestion rate (IR, Isochrysis galbana cells $\left.\mu \mathrm{l}^{-1}\right)$ and clearance rate $\left(\mathrm{CR}, \mu \mathrm{h}^{-1}\right)$ as a function of ash-free dry weight (AFDW, $\mu$ g) for larvae feeding on different $I$. galbana concentrations $\left(C\right.$, cells $\left.1^{-1}\right)$; $a$ : intercept $( \pm \mathrm{SE})$; $b$ : slope

\begin{tabular}{|c|c|c|c|c|}
\hline$C$ & $\ln a$ & $b$ & $r$ & $p$ \\
\hline \multicolumn{5}{|c|}{$\mathrm{IR}=a \mathrm{AFDW} W^{b}$} \\
\hline 10 & $4.04 \pm 0.140$ & $0.40 \pm 0.103$ & 0.775 & $<0.005$ \\
\hline 50 & $5.37 \pm 0.161$ & $0.59 \pm 0.118$ & 0.846 & $<0.001$ \\
\hline 100 & $5.74 \pm 0.122$ & $0.80 \pm 0.090$ & 0.942 & $<0.001$ \\
\hline 200 & $6.43 \pm 0.126$ & $0.81 \pm 0.093$ & 0.940 & $<0.001$ \\
\hline 300 & $6.45 \pm 0.153$ & $0.88 \pm 0.125$ & 0.919 & $<0.001$ \\
\hline \multicolumn{5}{|c|}{$\mathrm{CR}=a \mathrm{AFDW} W^{b}$} \\
\hline 10 & $1.76 \pm 0.194$ & $0.37 \pm 0.142$ & 0.638 & $<0.05$ \\
\hline 50 & $1.73 \pm 0.200$ & $0.68 \pm 0.147$ & 0.825 & $<0.001$ \\
\hline 100 & $1.42 \pm 0.150$ & $0.85 \pm 0.110$ & 0.926 & $<0.0001$ \\
\hline 200 & $1.23 \pm 0.148$ & $0.86 \pm 0.109$ & 0.929 & $<0.0001$ \\
\hline 300 & $0.79 \pm 0.249$ & $0.94 \pm 0.203$ & 0.839 & $<0.005$ \\
\hline
\end{tabular}
$( \pm \mathrm{SE}) \mathrm{r}$ : correlation coefficient; $\mathrm{p}$ : probability level

with exponent $b<1$ (Table 1). At lower algal cell concentration, ingestion rate exponent is very low ( $b=$ 0.40 ) indicating higher weight-specific ingestions in smaller larvae. Increasing concentration caused not only an increase in the intercepts, i.e. higher ingestions, but also an increase in the slopes which approach to $b=1$, i.e. constant weight-specific ingestion rates. A similar pattern is reflected by the exponents of the allometric clearance rate equations, but higher concentrations caused lower intercepts (lower clearance rate values).

\section{Food concentration}

The ingestion rate (Fig. 1a to d) increased with food concentration up to an optimum reached at 200 cells $\mu \mathrm{l}^{-1}$. Further increases of food failed to enhance the ingestion rate except for $196 \mu \mathrm{m}$ larvae, which showed maximum ingestion at 300 cells $\mu^{-1}$ (Fig. 1c). In general, clearance rate decreased when food concentration increased within the experimental range at all developmental stages tested (Fig. 1a to d). However, this decrease is less marked in larger larvae.

ANOVA showed highly significant differences ( $p<$ 0.0001 ) in the ingestion rate between sizes and food concentrations, as well as for the interaction between both factors $(p<0.001)$. There also were significant differences $(p<0.0001)$ in clearance rate between larval sizes and food concentrations, whereas the interaction of both factors was not significant ( $p>0.05$ ).

Feeding rates (IR and CR) could be described as functions of food concentration (C), dry weight (DW) and their interaction by means of the following 
multiple regression equations, where all variables are highly significant $(\mathrm{p}<0.01)$

$$
\begin{aligned}
\ln I R= & 3.70+0.29 \ln D W+0.016 C-0.42 \times 10^{-4} C^{2} \\
& +0.0029 D W C \quad(r=0.913, p<0.0001) \\
\ln C R= & 2.65+0.62 \ln D W-0.49 \ln C+0.0013 D W C \\
& (r=0.738, p<0.0001)
\end{aligned}
$$

\section{DISCUSSION}

The decrease in the rate of capture of suspended particles by filter feeders at increasing concentrations has been interpreted as an active mechanism-denominated functional response (recently reviewed by Hawkins \& Bayne 1992). Winter (1978) stated that this response occurs once ingestion capacity of the animal reaches saturation. Following this model, clearance rate is maximum and constant from a very low concentration threshold up to a seston load of $2 \mathrm{mg} \mathrm{l}^{-1}$, which includes the range of variation usual in the wild. This model does not seem to apply to veliger larvae, since clearance rate has been proven to decrease as soon as particulate food concentration exceeds $0.1 \mathrm{mg} \mathrm{l}^{-1}$ for Mytilus edulis (Sprung 1984a), $0.2 \mathrm{mg} \mathrm{l}^{-1}$ for Patinopecten yessoensis (MacDonald 1988) or $0.6 \mathrm{mg} \mathrm{l}^{-1}$ for Ostrea edulis (Crisp et al. 1985). In the present experiment with $R$. decussatus, clearance rate decreased at any concentration higher than the minimum assayed (0.2 $\left.\mathrm{mg} \mathrm{l}^{-1}\right)$, especially in younger larvae, whilst ingestion reached saturation at much higher concentrations (4 $\mathrm{mg} \mathrm{l}^{-1}$ ). Therefore, the so-called functional response causing a decrease in clearance rate would appear, in any case, well before larvae meet their ingestion capacity.

Previous workers on bivalve larvae agree that ingestion rate increases linearly with food concentration until saturation. However, controversy has arisen regarding the concentration at which the plateau is reached. Thus, Sprung (1984a) and MacDonald (1988) showed saturation of ingestion at relatively low concentrations of food ( 5 to 20 Isochrysis galbana cells $\mu^{-1}$ ). In contrast, Wilson (1979) and Crisp et al. (1985) found saturation of ingestion at much higher concentrations (250 to 300 cells $\mu^{-1}$ ).
Experimental evidence is presented here supporting high ingestion capacity by veliger larvae. Nevertheless, differences in test species, larval sizes and culture conditions (such as larval density) may explain this discrepancy.

Some previous studies have related the decrease in clearance rate at higher algal concentrations with filling of the gut and saturation of the digestive capacity (Riisgard et al. 1980, Riisgard 1988). As mentioned above, however, food concentrations causing this decrease are considerably lower than those saturating the ingestion capacity of the larvae.

An alternative model to describe the relationship between food concentration and larval feeding rates is presented here, based on the following. (1) The effi-
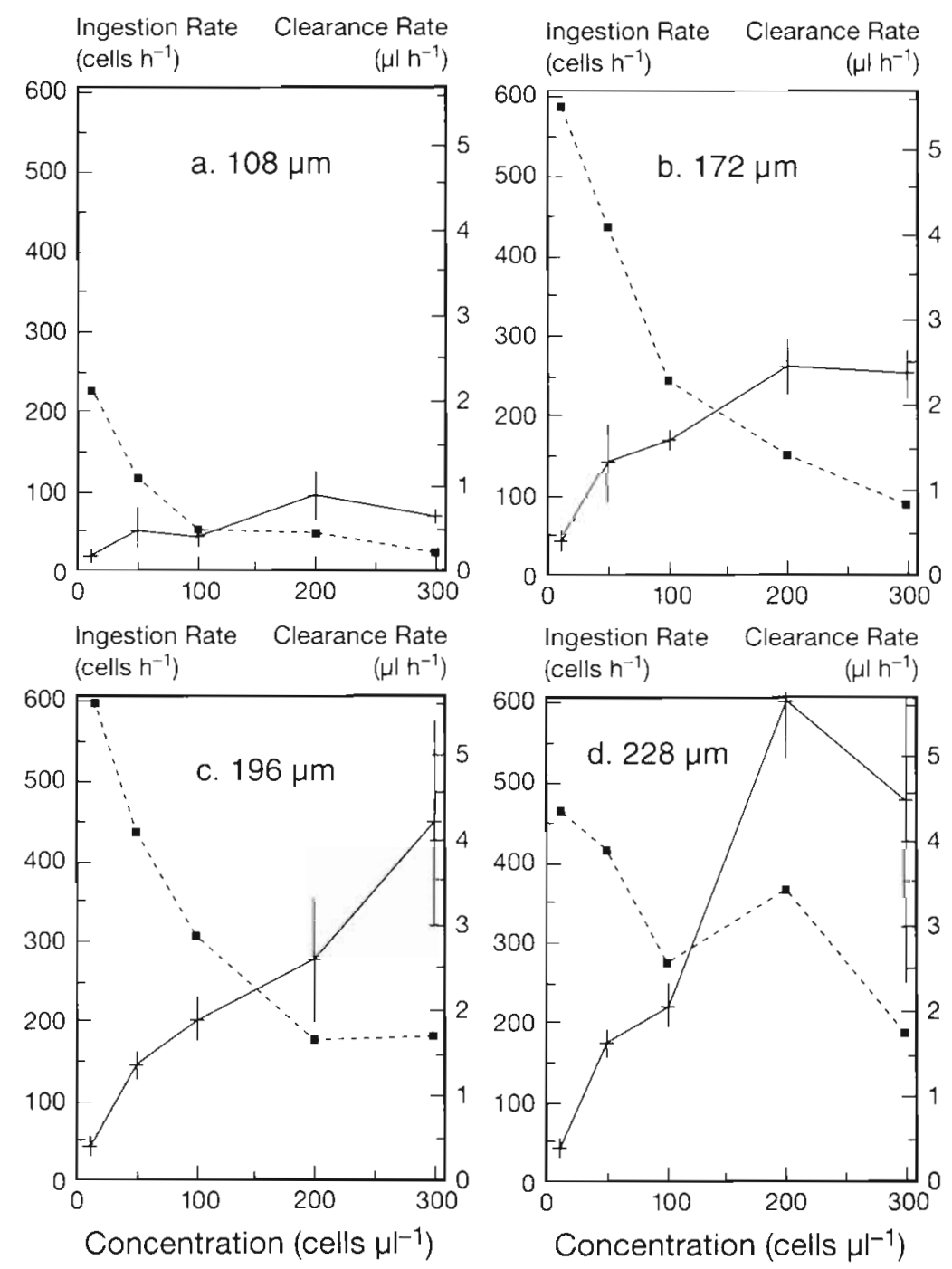

Fig. 1. Ruditapes decussatus. Ingestion rate (- - ) and clearance rate (----) for larvae of (a) $108 \mu \mathrm{m}$, (b) $172 \mu \mathrm{m}$, (c) $196 \mu \mathrm{m}$ and (d) $228 \mu \mathrm{m}$ shell length fed on different Isochrysis galbana cell concentrations. Values are means \pm SD of 3 replicates. Error bars represent $\pm S D$ 
ciency of the process of feeding in veliger larvae is very low, i.e. only a small proportion of the particles moved by the water currents caused by the velar cilia are actually captured and ingested. (2) As a consequence of interference among food particles, the efficiency of capture of these particles decreases when concentration increases. (3) At a certain particle concentration which is a function of the larval size, saturation of the ingestion capacity is reached, due to either excessive interference among particles, limited gut volume and/or limited food processing ability. (4) Maximum ingestion capacity, and not maximum clearance rate, is the relevant parameter from both ecological and zootechnical standpoints, since this is the parameter upon which maximum larval growth depends.

Veliger feeding mechanism has little in common with the highly efficient mechanism of particle retention in the gills of adult bivalves. Gallager (1988) calculated that the water flow through the effective capture zone of veliger larvae constituted only between 15 and $30 \%$ of the total flow through the velum and that not even all the particles entering this area were ultimately captured. Further, there was no significant difference in cirral beat frequency or velocity for larvae exposed to different Isochrysis galbana concentrations ranging from 0.1 to 1000 cells $\mu^{-1}$, i.e. water flow through the velum was independent of algal cell concentration (Gallager 1988). On the other hand, concentration did affect the efficiency of capture of food particles from the water current caused by the velum, which was $17 \%$ at low algal concentrations and markedly decreased at concentrations higher than 100 cells $\mu^{-1}$ (for $259 \mu \mathrm{m}$ length Mercenaria mercenaria larvae; Gallager 1988)

Therefore, ingestion rate can be expressed as a function of flow through the velum $\left(F, \mu l h^{-1}\right)$, particle concentration $\left(C\right.$, cell $\left.\mu l^{-1}\right)$ and efficiency of capture $(E, \%)$;

$$
I R=F C E / 100
$$

where, due to interference among particles, $E$ is inversely related to $C$. By using this equation on the present data, this efficiency of capture can be calculated as a function of cell concentration. For example, assuming larvae of $172 \mu \mathrm{m}$ length, an approximate value of water flow of $50 \mu \mathrm{l} \mathrm{h} \mathrm{h}^{-1}$ through the velum of larvae of this size (Strathmann \& Leise 1979, Gallager 1988), and ingestion rate from Fig. $1 \mathrm{~b}$, the efficiency values at $10,50,100,200$ and 300 cells $\mu l^{-1}$ were 8.4 , $5.6,3.3,2.6$ and $1.7 \%$ respectively. Hence, the efficiency of particle capture can be described as an inverse function of particle concentration within the experimental range (Fig. 2), following the equation (SE of the fitting parameters in parentheses):

$100 / E=10.8(2.15)+0.158(0.0128) C_{i} \quad \mathrm{r}=0.990, \mathrm{n}=5$

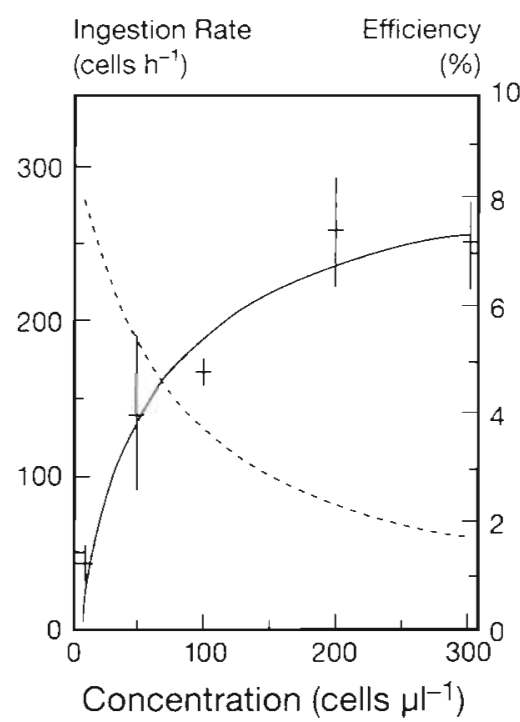

Fig. 2. Ruditapes decussatus. Ingestion rate (IR, - ) expressed as a hyperbolic function of particle concentration and efficiency of capture (-..-.) of food particles (Isochrysis galbana algal cells) for larvae of $172 \mu \mathrm{m}$ shell length. The theoretical model for IR plotted assumes an increasing degree of interference among particles which progressively reduces the efficiency of capture of food particles. Actual IR values (mean $\pm \mathrm{SD}$ ) are also plotted for comparison

Therefore, following this model, the theoretical IR of a $172 \mu \mathrm{m}$ larvae results in a hyperbolic function of $C$ :

$$
\mathrm{IR}=50 \mathrm{C} /(10.8+0.158 C)
$$

As illustrated in Fig. 2, there was good agreement between the theoretical ingestion rate derived from the model and the actual values recorded.

Some authors have resorted to the study of larval clearance rates at very low algal concentrations in an attempt to meet more ecologically realistic conditions (Riisgard et al. 1980, 1981, Jespersen \& Olsen 1982, Sprung 1984a). However, it has been shown that individual adult molluscs feed on monoalgal cultures at rates that differ from their response to the concentration of natural seston (e.g. Winter 1976). The ecological relevance of maximum filtration capacity found at 2 cells $\mu^{-1}$ of Isochrysis galbana (or Monochrysis lutheri) (Riisgard et al. 1980, 1981, Sprung 1984a) is further questioned by the experimental evidence that these low concentrations are insufficient to support optimal growth, or indeed any growth at all (Jespersen \& Olsen 1982, Sprung 1984b, Crisp et al. 1985, Pechenik et al. 1990, Beiras 1992). According to the energy balance, faster larval growth is achieved at environmental conditions supporting higher rates of energy acquisition. The food ration meeting this requirement is the ingestion capacity (Sprung 1984a), which is equivalent to the maximum ingested ration 


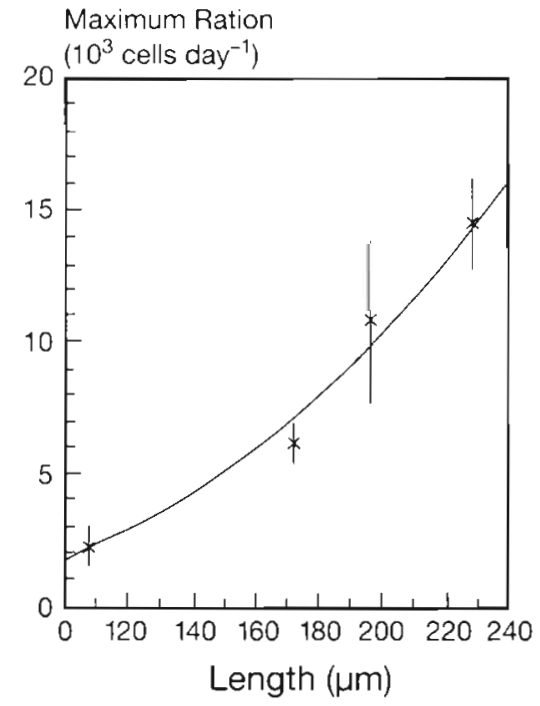

Fig. 3. Ruditapes decussatus. Maximum ration ingested daily by a larva fed on Isochrysis galbana as a function of larval length. Values are mean $\pm \mathrm{SD}$ of 3 replicates. See equation of the logarithmic model fitted in the text

(MR), a parameter commonly used in nutrition studies of marine animals (reviewed by Brett 1979). In the present study, the maximum ration varied throughout larval development, as illustrated in Fig. 3, according to the equation:

$\ln \mathrm{MR}=6.06(0.229)+0.0158(0.00126) L_{i} \mathrm{r}=0.994, \mathrm{n}=4$

where, for practical reasons, larval development is presented as length $(L, \mu \mathrm{m})$ and maximum ration as $I$. galbana cells ingested daily per larvae. Equivalences for other food sources can be calculated from the organic weight of $I$. galbana: $10^{6}$ cells $=20 \mu \mathrm{g}$ organic matter (authors' unpubl. data).

Acknowledgements. We thank C. Fernández for her helpful technical assistance and I. Allen for correcting the English. This study was funded by CICYT-CSIC-IEO project I+D number MAR90-0821-C02-01. Two of us (R.B. and M.A.) were supported by grants from the Spanish Ministry of Education. and Science (FPI Fellowships) during the course of the work.

\section{LITERATURE CITED}

Bayne, B. L., Worrall, C. M. (1980). Growth and production of mussels Mytilus edulis from two populations. Mar. Ecol. Prog. Ser. 3: 317-328

Beiras, R. (1992). Fisiología del crecimiento en larvas y postlarvas de Ostrea edulis L. Aplicaciones para el cultivo en criadero. Ph.D. thesis, University of Santiago de Compostela

Beiras, R., Pérez-Camacho, A., Albentosa, M. (1990). Tasas de filtración en larva de ostra (Ostrea edulis L.). In: Landín, A., Cervino, A. (eds.) Proceedings of the third National Congress on Aquaculture. Experimental Centre of Vilaxoán, Pontevedra
Beiras, R., Pérez-Camacho, A., Albentosa, M. (1993). Influence of food concentration on energy balance and growth performance of Venerupis pullastra seed reared in an open flow system. Aquaculture 116: 353-365

Beiras, R., Pérez-Camacho, A.. Albentosa, M. (1994a). Comparison of the scope for growth with the growth performance of Ostrea edulis L. seed reared at different food concentrations in an open-flow system. Mar. Biol. 119: $227-233$

Beiras, R., Pérez-Camacho, A., Albentosa, M. (1994b). Influence of temperature on the physiology of growth in Ruditapes decussatus (L.) larvae. J. Shellfish Res. 13(1): 77-83

Brett, J. R. (1979) Environmental factors and growth. In: Hoar, W. S., Randall, D. J., Brett, J. R. (eds.) Fish physiology, Vol. 8. Academic Press, New York

Crisp, D. J., Yule, A. B., White, K. N. (1985). Feeding by oyster larvae: the functional response, energy budget and a comparison with mussel larvae. J. mar. biol. Ass. U.K. 65 : $759-783$

Dame, R. F. (1972). The ecological energetics of growth, respiration and assimilation in the intertidal American oyster, Crassostrea virginica. Mar. Biol. 17: 243-250

Gallager, S. M. (1988). Visual observations of particle manipulation during feeding in larvae of a bivalve mollusc. Bull. mar. Sci. 43(3): 344-365

Griffiths, C. L., Griffiths, R. J. (1987). Bivalvia. In: Pandian, T. J., Vernberg, F. J. (eds.) Animal energetics, Vol. 2. Academic Press, p. 1-88

Griffiths, C. L., King, J. A. (1979). Some relationships between size, food availability and energy balance in the ribbed mussel Aulacomya ater. Mar. Biol. 51. 141-149

Hawkins, A. J. S., Bayne, B. L. (1992). Physiological interrelations, and the regulation of production. In: Gosling, E. (ed.) The mussel Mytilus: ecology, physiology, genetics and culture. Elsevier, Amsterdam

Jespersen, H., Olsen, K. (1982). Bioenergetics in veliger larvae of Mytilus edulis L. Ophelia 21: 101-113

MacDonald, B. A. (1988). Physiological energetics of Japanese scallop Patinopecten yessoensis larvae. J. exp. mar. Biol. Ecol. 120: 155-170

Navarro, J. M., Winter, J. E. (1982). Ingestion rate, assimilation efficiency and energy balance in Mytilus chilensis in relation with body size and different algal concentrations. Mar. Biol. 67: 255-266

Newell, R. C., Johnson, L. G., Kofoed, L. H. (1977). Adjustment of the components of energy balance in response to temperature change in Ostrea edulis. Oecologia 30 : $97-110$

Pechenik, J. A., Eyster, L. S., Widdows, J., Bayne, B. L. (1990). The influence of food concentration and temperature on growth and morphological differentiation of blue mussel Mytilus edulis L. larvae. J. exp. mar. Biol. Ecol. 136: 47-64

Pérez-Camacho, A., Román, G. (1973). El desarrollo larvario de Venerupis pullastra. Boin. Inst. esp. Oceanogr. 165: $3-36$

Pérez-Camacho, A., Román, G., Torre, M. (1977). Experiencias en cultivo de larvas de tres especies de moluscos bivalvos: Venerupis pullastra (Montagu), Venerupis decussata (Linnaeus) y Ostrea edulis (Linnaeus). Boln. Inst. esp. Oceanogr. 235: 10-61

Riisgard, H. U. (1988). Feeding rates in hard clam (Mercenaria mercenaria) veliger larvae as a function of algal (Isochrysis galbana) concentration. J. Shellfish Res. 7: $377-380$

Riisgard, H. U., Randlov, A., Hamburger, K. (1981). Oxygen consumption and clearance rate as a function of size in Mytilus edulis L. veliger larvae. Ophelia 20: 179-183 
Riisgard, H. U., Randlov, A., Kristensen, P. S. (1980). Rates of water processing, oxygen consumption and efficiency of particle retention in veligers and young post-metamorphic Mytilus edulis. Ophelia 19: 37-47

Sokal, R. R., Rohlf, F. J. (1969). Biometry. W. H. Freeman and Co., San Francisco

Sprung, M. (1984a). Physiological energetics of mussel larvae (Mytilus edulis). II. Food uptake Mar. Ecol. Prog. Ser. 17: 295-303

Sprung, M. (1984b). Physiological energetics of mussel larvae (Mytilus edulis). IV. Efficiencies. Mar. Ecol. Prog. Ser. 18: $179-186$

Strathmann, R. R., Leise, E. (1979). On feeding mechanisms and clearance rates of molluscan veligers. Biol. Bull. 157 : $524-535$

Thompson, R. J., Bayne, B. L. (1974). Some relationships between growth, metabolism and food in the mussel Mytilus edulis. Mar. Biol. 27: 317-326

This article was submitted to the editor
Walne, P. R. (1965). Observations on the influence of food supply and temperature on the feeding and growth of the larvae of Ostrea edulis L. Fish. Invest. Lond. 24(2): 1-45

Widdows, J., Johnson, D. (1988). Physiological energetics of Mytilus edulis: scope for growth. Mar. Ecol. Prog. Ser. 46: 113-121

Wilson, J. H. (1979). Observations on the grazing rates and growth of Ostrea edulis L. larvae when fed algal cultures of different ages. J. exp. mar. Biol. Ecol. 38: 187-199

Winter, J. (1976). Feeding experiments with Mytilus edulis L. at small laboratory scale. II. The influence of suspended silt in addition to algal suspensions on growth. In: Persoone, G., Jaspers, E. (eds.) Proc. 10th Eur. Symp. Mar. Biol., Vol. 1. Universa Press, Wetteren, p. 583-600

Winter, J. (1978). A review on the knowledge of suspensionfeeding in lamellibranchiate bivalves, with special reference to artificial aquaculture systems. Aquaculture 13: $1-33$

Manuscript first received: May 9, 1994

Revised version accepted: September 8, 1994 